\title{
STANDARYZACJA OPRACOWANIA ZBIORÓW W BIBLIOTECE AKADEMICKIEJ
}

\begin{abstract}
The article presents changes in the standardization of cataloging library collections on the example of cataloging books in the OPACs in libraries cooperating with NUKAT (central catalog of scientific libraries) and cataloging of periodicals in electronic databases in the project "Central Open Science Library". The direction of changes in the standardization of cataloging of library collections and the reason why it plays a special role in customer service, are just some of the problems that the author has taken in this article. The problems described in the article do not reflect the whole overview of the situation, they only indicate trends associated with dynamic changes in cataloging of scientific collections, which are important in customer service.
\end{abstract}

Slowa kluczowe: katalogowanie zbiorów, biblioteki akademickie, katalog komputerowy, bazy danych

Standaryzacja opracowania zbiorów będących przedmiotem zainteresowania biblioteki akademickiej obejmuje coraz większy obszar aktywności ludzkiej. Zmianie ulegają standardy technologii, zapisu i jakości danych w systemie. W efekcie standaryzacja przekształciła się w proces nieustannie doskonalony, w którym znaczenia nabierają dokumenty alternatywne i otwartość bibliotek na współpracę. Obok bibliotek, opracowaniem zasobów naukowych zajmują się wydawcy oraz redakcje czasopism stosujące własne instrukcje wprowadzania danych. Wszystko wynika ze zmiany warunków funkcjonowania i priorytetów w zarządzaniu organizacją.

Zarządzanie biblioteką nastawione na konkurencyjność wymusza nowe podejście do opracowania zbiorów w dążeniu do poprawy jakości katalogowania zarówno książek, jak i czasopism. Dużo uwagi zwraca się na opracowanie zawartości czasopism w bazach danych. W ustalaniu standardów katalogowania liczy się jakość wyszukiwania ukierunkowana na potrzeby i wygodę użytkownika.

W artykule przedstawiono zmiany dotyczące standaryzacji katalogowania zbiorów bibliotecznych na przykładzie opracowania książek w katalogach komputerowych bibliotek współpracujących z Centrum NUKAT Katalogiem 
Zbiorów Polskich Bibliotek Naukowych oraz opracowania czasopism w elektronicznych bazach danych dostępnych w projekcie Centrum Otwartej Nauki (CEON) Biblioteka Nauki. W jakim kierunku zmierza standaryzacja opracowania zbiorów bibliotecznych oraz dlaczego odgrywa szczególną rolę w obsłudze klienta, to tylko niektóre z problemów, które autor podjął w niniejszym artykule.

\section{Wokół problemów działalności standaryzacyjnej}

Działalność standaryzacyjna opracowania zbiorów w bibliotece akademickiej polega na pozyskiwaniu z zewnątrz, jak i opracowaniu na miejscu dokumentów, zgodnie z którymi mają przebiegać powtarzalne czynności zmierzające do zapewnienia określonej jakości usług i zwiększenia konkurencyjności ${ }^{1}$. W Polsce zauważa się niedostatek aktualnych norm PN, które „kompleksowo i jednoznacznie wytyczałyby zasady tworzenia opisu bibliograficznego różnego typu dokumentów" ". Stąd znaczenia nabierają dokumenty alternatywne. Sposób wykonywania czynności w zakresie opracowania zbiorów jest opisany i regulowany wzajemnie uzupełniającymi się źródłami, którymi są normy ${ }^{3}$, instrukcje, rozporządzenia, zalecenia. Bez względu na rodzaj tych źródeł działalność standaryzacyjna musi spełniać wymagania:

- $\quad$ standardy muszą być wypracowywane przez grono specjalistów i praktyków, co zapewnia skuteczność nowych reguł w codziennym działaniu;

- $\quad$ standardy powinny być okresowo przeglądane, aby dostosować je do aktualnych warunków;

- $\quad$ pracowników należy przeszkolić merytorycznie w celu właściwego wykonywania powierzonych czynności;

- $\quad$ standardy muszą zapewnić poprawę jakości realizowanych czynności ${ }^{4}$.

Katalogowanie zbiorów w swej istocie polega na wprowadzaniu danych w serwisach elektronicznych, co określa warunki do modyfikowania opisu $\mathrm{i}$ transferu danych pomiędzy serwisami w sieci. Korzystanie z serwisów elektronicznych wymaga zapoznania się z zagadnieniem metadanych. Dlaczego? „Metadane umożliwiają użytkownikom wyszukanie potrzebnej informacji $\mathrm{w}$ cyberprzestrzeni wraz $\mathrm{z}$ odpowiedzią na pytanie, w jakiej relacji pozostaje

\footnotetext{
${ }^{1}$ J. Łunarski, Normalizacja i standaryzacja, Rzeszów 2014, s. 173.

${ }^{2}$ M. Rowińska, NUKAT. Z zasady trzymamy się zasad, „Biuletyn EBIB” 2015, nr 7 (160), http://open.ebib.pl/ojs/index.php/ebib/article/view/382, [dostęp: 02.02.2017].

${ }^{3}$ Szerzej: M. Stanula, Polskie normy w zakresie opisu bibliograficznego dokumentów, „FIDES. Biuletyn Bibliotek Kościelnych” 1998, nr 1, s. 92-109.

${ }^{4}$ J. Łunarski, op. cit., s. 177-178.
} 
ona do innych informacji5” zauważa Marek Nahotko. Według Mirosława Górnego ,standardy związane z metadanymi mogą opierać się na dwóch podstawowych wytycznych: związanych $\mathrm{z}$ warunkami technologicznymi i związanych z poziomem efektywności wyszukiwania. Jednak możemy uznać [zauważa autor], że absolutnym priorytetem jest efektywność wyszukiwania. Ale trzeba tę efektywność zdefiniować (niekoniecznie w odniesieniu tylko do potrzeb czytelnika, mogą być to też potrzeby bibliotekarza, który wyszukuje jakiś dokument w ramach swoich rutynowych działań)"6.

Zasady zalecane przez International Federation of Library Associations and Institutions (IFLA) dotyczące standardu danych bibliograficznych w OPAC i elektronicznych bazach danych skoncentrowano wokół wartości:

- $\quad$ wygoda użytkownika: opis i punkty dostępu powinny ułatwiać wyszukiwanie zasobów;

- $\quad$ powszechne użycie: język naturalny stosowany przez użytkowników;

- reprezentatywność: forma pisowni zgodna z zapisem w źródle opisywanym;

- $\quad$ spójność i standaryzacja: znormalizowanie struktury opisów, w tym punktów dostępu na potrzeby wymiany danych ${ }^{7}$.

W bazach danych czy OPAC metadane są rozpatrywane ze względu na elementy opisu i ich wzajemne relacje, sposób ich zapisu, jak również punkty dostępu do opisywanej jednostki.

\section{NUKAT Katalog Zbiorów Polskich Bibliotek Naukowych}

Koordynacja prac w Katalogu Zbiorów Polskich Bibliotek Naukowych NUKAT spoczywa na specjalistach Centrum NUKAT w Bibliotece Uniwersyteckiej w Warszawie. Centrum reguluje zasady katalogowania zbiorów w katalogach komputerowych bibliotek polskich uczelni typu: uniwersytety, uczelnie techniczne, wszystkie akademie wychowania fizycznego i uniwersytety ekonomiczne i innych. Liczba bibliotek uczestniczących w projekcie stale wzrasta. Współpraca czynna polega na współtworzeniu opisów (bibliograficznych i kartoteki haseł wzorcowych) w centralnym katalogu i ich pobieraniu z centralnej

\footnotetext{
${ }^{5}$ M. Nahotko, Metadane, „Biuletyn EBIB” 2000, nr 6 (14), http://www.oss.wroc.pl/ biuletyn/ebib14/nahotko.html, [dostęp: 02.02.2017].

${ }^{6}$ M. Górny, Standaryzacja i unifikacja - kłopot czy korzyści?, [w:] Polskie biblioteki akademickie w Unii Europejskiej, Łódź 23-25 czerwca 2004 r. Materiały konferencyjne, Łódź 2004, s. 16.

${ }^{7}$ Deklaracja Międzynarodowych Zasad Katalogowania, IFLA, 2009, http://www.ifla.org/ files/assets/cataloguing/icp/icp_2009-pl.pdf, [dostęp: 02.02.2017].

${ }^{8}$ M. Jóźwiak, Katalog centralny NUKAT - dziesięć lat współkatalogowania, „FIDES. Biuletyn Bibliotek Kościelnych” 2014, nr 1 (38), s. 119.
} 
bazy do lokalnych OPAC, a współpraca bierna tylko na pobieraniu opisów9 Współtworzenie opisów w NUKAT wiąże się w bibliotece z posiadaniem systemu bibliotecznego, który „powinien spełniać międzynarodowe standardy i prawidłowo obsługiwać formaty zapisu danych i wymiany danych"10. Efektywność czynnej współpracy przekłada się na skrócenie czasu katalogowania i wyszukiwania zbiorów, zachowanie spójności i jakości danych, szybkie napełnianie centralnego serwisu opisami. Wartość informacyjna opisów w serwisie wynika z przyjętego standardu katalogowania.

\section{Standard katalogowania książek w NUKAT}

Ostatnio w katalogu NUKAT zmodyfikowano zasady katalogowania książek uwzględniające standardy katalogowania format MARC $21^{11}$ i norma PNN-01152-1:1982 Opis bibliograficzny - ksiązki, na skutek wdrażania standardu Resource Description and Access (RDA) ${ }^{12}$. „RDA to nowy standard katalogowania, który zastępuje drugie wydanie angloamerykańskich zasad katalogowania (Anglo-American-Cataloguing Rules - AACR2). RDA jest rozwijane w celu przystosowania katalogów bibliotecznych do pełnego wykorzystywania możliwości oferowanych przez nowoczesne systemy bazodanowe i udostępnienia użytkownikom bibliotek efektywnych i funkcjonalnych narzędzi usprawniających dostęp do informacji. Kluczowe znaczenie dla rozwoju tego standardu miało powiązanie go z rozwijanymi przez IFLA konceptualnymi modelami dla danych bibliograficznych i wzorcowych. [...] RDA jest standardem podlegającym ciągłym przeobrażeniom, których celem jest przekształcenie go w standard akceptowany przez bibliotekarzy wywodzących się z różnych kręgów kulturowych, jak również przez instytucje spoza sektora bibliotecznego"13.

Zmiany wprowadzone w NUKAT w pierwszej fazie objęły zapis danych o książkach drukowanych i online wydanych od stycznia 2015 r. i dotyczą:

- „zniesienia zasady podawania do trzech autorów;

- $\quad$ pełnego oddawania informacji przejętych z podstawowych źródeł danych;

- rezygnacji ze stosowania skrótów wyrazów i wyrażeń w opisie bibliograficznym" $"$.

\footnotetext{
${ }^{9}$ Ibidem, s. $121-122$.

${ }^{10}$ M. Rowińska, op. cit.

${ }^{11}$ Zob.: Format MARC 21 rekordu bibliograficznego dla ksiązki, Warszawa 2012.

${ }^{12}$ Szerzej: J. Franke, RDA (Resource Description and Access) - geneza i koncepcja, „Przegląd Biblioteczny” 2015, R. 83, nr 1, s. 7-61.

${ }^{13}$ RDA Resource Description \& Access, Grupa Robocza ds. Standardów Bibliograficznych, http://centrum.nukat.edu.pl/rda/o-rda/, [dostęp: 02.02.2017].

${ }^{14}$ Zmiana zasad podawania autorów/twórców w hastach głównych (pola 100/110/111) $i$ hastach dodatkowych (pola 700/710/711) oraz w strefie tytulu i oznaczenia odpowiedzialności,
} 
Odstąpienie od zasady podawania trzech autorów dało możliwość wyszukiwania książki według wszystkich autorów wymienionych na stronie tytułowej, odwrocie strony tytułowej i w innych podstawowych źródłach opisu. W strefie tytułu i oznaczenia odpowiedzialności (pole 245) obok odpowiedzialności autorskiej wymienia się wszystkie inne odpowiedzialności ze strony tytułowej. Co znaczy, w przypadku książki napisanej przez dziesięciu autorów, że wszyscy są wpisywani w polu 245 i dodatkowo wyłączając autora pierwszego, w polach 700, pierwszy autor odnotowany jest jak dotąd w polu hasło główne - nazwa osobowa (pole 100). Hasło w polach 700 otrzymują: nazwy tłumaczy pozyskane z podstawowego źródła danych oraz nazwy ilustratorów, autorów wstępu, posłowia, przedmowy ze strony tytułowej ${ }^{15}$. Pełne oddawanie informacji w opisie polega także na wprowadzaniu:

- $\quad$ w polu 245 pełnego określenia odpowiedzialności w formie występującej w książce: „przekład”, „przełożyli”, „redaktor statystyczny”, „redaktorzy tematyczni”, „tłumaczenie”, ,wstęp do wydania” i innych;

- $\quad$ w strefie adresu wydawniczego pole (260) pełnej nazwy wydawnictwa.

Należy zauważyć, iż nowe zasady katalogowania zastosowano dotąd w bibliotekach uczestniczących w NUKAT, Bibliotece Narodowej i tylko w nielicznych samodzielnie katalogujących zbiory.

\section{CEON Biblioteka Nauki}

Biblioteka Nauki ogólnodostępny serwis Interdyscyplinarnego Centrum Modelowania Matematycznego i Komputerowego Uniwersytetu Warszawskiego (dalej ICM UW) obejmuje bezpłatne bazy danych: Agro - Biblioteki Uniwersytetu Przyrodniczego w Poznaniu; BazEkon - konsorcjum bibliotek głównie uniwersytetów ekonomicznych; BazTech - konsorcjum BazTech bibliotek głównie uczelni technicznych i uniwersytetów; CEJSH - Polskiej Akademii Nauk utworzone przez prezesów akademii nauk państw Grupy Wyszehradzkiej, czyli Czech, Polski, Słowacji, Węgier ${ }^{16}$; DML-PL ${ }^{17}$ i PSJD - ICM UW.

NUKAT, 2015, http://blog.nukat.edu.pl/images/files/ustalenia/bibliograficzne/zasada\%20trzech_ styczen_2015_tekst.pdf, [dostęp: 02.02.2017].

${ }^{15}$ Ibidem.

${ }^{16}$ L. Stępińska-Ustasiak, Czasopisma humanistyczne i społeczne otwieraja się $w$ bazie CEJSH, 2015, http://uwolnijnauke.pl/czasopisma-humanistyczne-i-spoleczne-otwieraja-sie-w-ba zie-cejsh/, [dostęp: 02.02.2017].

${ }^{17}$ Szerzej: K. Zamłyńska, DML-PL Polska Matematyczna Biblioteka Cyfrowa, [w:] Materiały konferencyjne EBIB, $\mathrm{nr} 24$, Bibliograficzne bazy danych i ich rola $w$ rozwoju nauki. II Konferencja Naukowa Konsorcjum BazTech, Poznań, 17-19 kwietnia 2013, http://open.ebib. pl/ojs/index.php/Mat_konf/article/view/48/148, [dostęp: 02.02.2017]. 
Informacje bibliograficzne $\mathrm{i}$ artykuły naukowe pochodzą $\mathrm{z}$ czasopism reprezentujących różne nauki, między innymi: przyrodnicze i rolnicze oraz dziedziny pokrewne, ekonomiczne, techniczne, ścisłe, społeczne, humanistyczne, matematyczne, medyczne, fizyczne, chemiczne, o kulturze fizycznej i inne. Artykuły występują w różnych językach, w tym znaczna część w języku angielskim i polskim.

Wprowadzanie metadanych do Biblioteki Nauki odbywa się na zasadzie:

- $\quad$ współpracy bezpośredniej, gdzie za opracowanie danych są odpowiedzialne redakcje czasopism baz CEJSH, PSJD;

- $\quad$ współpracy pośredniej, gdzie odpowiedzialność za dane ponoszą pozostałe bazy ${ }^{18}$.

\section{CEON Biblioteka Nauki: standardy opracowania zawartości czasopism}

Czasopisma widoczne w Bibliotece Nauki są wprowadzane na podstawie odrębnych instrukcji w odmiennych formatach i standardach opisu ${ }^{19}$. Instrukcje w poszczególnych bazach podlegają różnym modyfikacjom, w różnym okresie rozwoju bazy. Mają one na celu dodawanie w opisach bibliograficznych pól i danych wcześniej nie uwzględnianych $\mathrm{w}$ bazie. Wiele zmian nastąpiło dopiero po wdrożeniu programu DeskLight i posadowieniu baz na platformie YADDA CEON ${ }^{20}$. Większy zasób informacji odnotowano przez pola: „autorzy”, „abstrakty”, „słowa kluczowe”, „treść/zawartość”, „bibliografia” w opisach bibliograficznych artykułów i pola: „,inne tytuły”, „wydawca”"21, „witryna www”, „redakcja”, ,pełne teksty”, „pełne teksty dostępne lokalnie" w opisach bibliograficznych czasopism oraz uwagi, zasoby linkowane. W zależności od bazy wpisywane są dane:

${ }^{18}$ Szerzej: M. Strybel, Omówienie zasad udostępniania czasopism $w$ Bibliotece Nauki, Warszawa 2015, http://www.slideshare.net/OpenSciencePlatform/wspolpraca-z-biblioteka-nau ki, [dostęp: 02.02.2017].

${ }^{19}$ L. Derfert-Wolf, Indeksowanie czasopism naukowych $w$ krajowych bazach danych $w$ kontekście organizacyjno-ekonomicznym, [w:] red. M. Odlanicka-Poczobutt, K. Zioło, Biblioteka akademicka. Infrastruktura, uczelnia, otoczenie, Gliwice, 24-25 października 2013 r., Gliwice 2014, s. 195-196.

${ }^{20}$ Zob.: K. Zamłyńska, op. cit.

${ }^{21}$ Szczegółowe informacje na temat wydawcy dostępne są także w wyodrębnionym w bazie opisie wydawcy (opcja przeglądaj wydawcy w Bibliotece Nauki). Na strukturę takiego opisu składają się pola: nazwa, adres, dane kontaktowe, publikacje (tytuły czasopism), szerzej: D. Buzdygn, Bibliograficzna baza danych - promocja czasopism, artykułów, autorów i instytucji, [w:] Materiały konferencyjne EBIB, nr 24, Bibliograficzne bazy danych i ich rola $w$ rozwoju nauki. II Konferencja Naukowa Konsorcjum BazTech, Poznań, 17-19 kwietnia 2013, http://open. ebib.pl/ojs/index.php/Mat_konf/article/view/22, [dostęp: 02.02.2017]. 
- $\quad$ zamiast inicjału pełne imię autora;

- określenia autorów jak „student”, „doktorant”, tytuły naukowe wszystkich autorów lub tylko autorów polskich, afiliacja, adres e-mail autora;

- abstrakty występujące w źródle, najczęściej w języku angielskim - od początku istnienia bazy, jak również w czasie jej rozwoju;

- dane o wskaźnikach oceny czasopism.

$\mathrm{Na}$ etapie przeszukiwania Biblioteki Nauki zasadnicze znaczenie mają słowa kluczowe w języku angielskim, stanowią bowiem punkt jednoczesnego dostępu do zasobów w różnych językach. Słowa kluczowe w języku polskim i angielskim są dodawane w opisach artykułów na następujących zasadach: obecności $\mathrm{w}$ czasopiśmie, thumaczenia $\mathrm{w}$ przypadku braku danej wersji językowej w artykułach polskojęzycznych i anglojęzycznych ${ }^{22}$, thumaczenia $\mathrm{z}$ języka polskiego na angielski $\mathrm{w}$ artykułach polskojęzycznych i tworzenia wyłącznie w języku angielskim w artykułach anglojęzycznych, tworzenia w przypadku ich braku:

- $\quad$ w artykułach w języku polskim przynajmniej w języku polskim;

- $\quad$ w artykułach w języku angielskim przynajmniej w języku angielskim;

- $\quad$ w artykułach w innym języku przynajmniej w języku polskim lub angielskim $^{23}$. W zależności od bazy słowa kluczowe są uzupełniane w opisach istniejących.

W sposób ciągły wzrasta ilość informacji o artykułach dostępnych online, w tym liczba odsyłaczy zamieszczanych w opisie. Opisy czasopism zawierają odsyłacze do archiwum między innymi na stronę wydawcy, De Gruyter Open, biblioteki cyfrowej. Zasób pełnych tekstów jest zależny od rozwoju samych czasopism, założeń organizatorów bazy i umów z wydawcami. W bazach DML -PL ${ }^{24}$ i PSJD pełne teksty znajdują się w opisach wszystkich artykułów, natomiast $\mathrm{w}$ Agro ${ }^{25}$, BazEkon, BazTech ${ }^{26}, \mathrm{CEJSH}^{27}$ ich dodawanie zainicjowano

${ }^{22}$ Z. Kasprzak, M. Polarczyk, Nowe elementy w rozwoju bazy Agro, [w:] Materiały konferencyjne EBIB, nr 24, Bibliograficzne bazy danych i ich rola w rozwoju nauki. II Konferencja Naukowa Konsorcjum BazTech, Poznań, 17-19 kwietnia 2013, http://open.ebib.pl/ojs/index.php/ Mat_konf/article/view/32/144, [dostęp: 02.02.2017].

${ }^{23}$ Instrukcja obstugi programu DeskLight dla bazy BazTech, [materiały niepublikowane], Oprac. 15.11.2010 z późn. zm.

${ }^{24} \mathrm{~K}$. Zamłyńska, op. cit.

${ }^{25}$ Z. Kasprzak, M. Polarczyk, op. cit.

${ }^{26}$ L. Derfert-Wolf, Baza danych BazTech - wspótpraca z wydawcami czasopism i użytkownikami, [w:] Materiały konferencyjne EBIB, nr 24, Bibliograficzne bazy danych i ich rola w rozwoju nauki. II Konferencja Naukowa Konsorcjum BazTech, Poznań, 17-19 kwietnia 2013, http://open.ebib.pl/ojs/index.php/Mat_konf/article/view/38/147, [dostęp: 02.02.2017].

${ }^{27}$ L. Stępińska-Ustasiak, op. cit. 
W różnym okresie tworzenia bazy. W postaci pliku występują pojedyncze zeskanowane artykuły starych roczników, które nie posiadały wersji elektronicznej, artykuły opublikowane w wersji papierowej i online oraz artykuły wyłącznie elektroniczne. Ostatnio następuje dynamiczny wzrost opisów artykułów wraz z artykułem PDF zarchiwizowanym w Bibliotece Nauki, jak i numerem DOI artykułu.

Zmiany w opracowaniu artykułów polegają także na obowiązku dodawania bibliografii załącznikowej, co umożliwia analizę cytowań prac autora $\mathrm{w}$ oparciu o serwis ${ }^{28}$. W wielu bazach w starszych opisach brak bibliografii jest sukcesywnie uzupełniany. Podkreśla się niedoskonałości bibliografii w czasopismach indeksowanych w bazach danych, takie jak brak bibliografii i konieczność tworzenia bibliografii przez bibliotekarzy z istniejących przypisów ${ }^{29}$.

Do standardu opracowania artykułów i czasopism należy zamieszczanie pełnych danych bez skrótów wyrazów/wyrażeń w opisach.

\section{Wnioski}

Stawianie na jakość i ciągłe doskonalenie standardów opracowania zbiorów w bibliotece akademickiej wynika z postępującej globalizacji, w której coraz więcej podmiotów organizuje i aktywnie uczestniczy w tworzeniu elektronicznych serwisów dokumentów. Standaryzacja procesu opracowania zbiorów zmierza ku rozwojowi i elastyczności danych, ich dostępności w środowisku sieciowym na nowych zasadach ${ }^{30}$.

Większość bibliotek samodzielnie katalogujących książki nie zna nowych standardów katalogowania przyjętych przez Centrum NUKAT i pracuje bez zmian. Zjawisko to pokazuje $\mathrm{z}$ jednej strony, jak ważna dla biblioteki jest współpraca w ramach projektów krajowych, dzięki którym opracowanie zbiorów przebiega według uznanych wzorców, $\mathrm{z}$ drugiej strony jak istotne jest nowoczesne oprogramowanie zapewniające jakość i spójność danych z innymi serwisami w sieci, czy linkowanie danych.

${ }^{28}$ Zob.: A. Osiewalska, BazEkon - dziedzinowy indeks cytowań z własnym programem bibliometrycznym, [w:] Materiały konferencyjne EBIB, $\mathrm{nr}$ 24, Bibliograficzne bazy danych $i$ ich rola w rozwoju nauki. II Konferencja Naukowa Konsorcjum BazTech, Poznań, 17-19 kwietnia 2013, http://open.ebib.pl/ojs/index.php/Mat_konf/article/view/33, [dostęp: 02.02.2017].

${ }^{29}$ L. Derfert-Wolf, Indeksowanie czasopism..., s. 197.

${ }^{30}$ Por.: J. Sadowska, Polskie dziedzinowe bibliograficzne bazy danych $w$ perspektywie lokalnej i globalnej, [w:] EBIB Materiały konferencyjne, nr 19, Bibliograficzne bazy danych. Kierunki rozwoju i możliwości wspótpracy. Ogólnopolska konferencja naukowa z okazji 10-lecia bazy danych BazTech, Bydgoszcz, 27-29 maja 2009, http://www.ebib.pl/publikacje/matkonf/ mat19/sadowska.php, [dostęp: 02.02.2017]. 
Obok istniejących norm znaczenia nabierają dokumenty alternatywne czyli instrukcje wprowadzania danych aktualizowane przez organizacje, konsorcja i zespoły koordynujące projekt. Dzięki wprowadzanym zmianom opisy książek, czasopism i zawartości czasopism są bardziej czytelne i zrozumiałe. W opisach wzrasta ilość danych o twórcach i opisywanych zasobach z różnych dziedzin wiedzy.

Opracowaniu i udostępnianiu w bazach danych podlegają także artykuły publikowane wyłącznie bezpłatnie online, czyli których brak w kolekcjach tradycyjnych bibliotek akademickich. Standaryzowanie poszczególnych elementów opisu wpływa na relewantność uzyskiwanych wyników. Wykazywanie zasobów katalogów komputerowych i baz danych różnych podmiotów w jednym serwisie zapewnia wysoką jakość usług oraz ułatwia dostęp do zasobów informacyjnych.

Opracowanie czasopism i ich zawartości w coraz większym zakresie spełnia normy przyjęte $\mathrm{w}$ sektorze szkolnictwa wyższego. Standaryzacja jest jednym z kluczowych elementów na drodze do ciągłego doskonalenia opracowania zbiorów i podnosi jakość usług bibliotek akademickich ${ }^{31}$.

\section{Bibliografia}

Buzdygan D., Bibliograficzna baza danych - promocja czasopism, artykułów, autorów i instytucji, [w:] Materiały konferencyjne EBIB, $\mathrm{nr} 24$, Bibliograficzne bazy danych i ich rola w rozwoju nauki. II Konferencja Naukowa Konsorcjum BazTech, Poznań, 17-19 kwietnia 2013, http://open.ebib.pl/ojs/index.php/Mat_konf/article/ view/22, [dostęp: 02.02.2017].

Deklaracja Międzynarodowych Zasad Katalogowania, IFLA, 2009, http://www.ifla. org/files/assets/cataloguing/icp/icp_2009-pl.pdf, [dostęp: 02.02.2017].

Derfert-Wolf L., Baza danych BazTech - wspótpraca z wydawcami czasopism i użytkownikami, [w:] Materiały konferencyjne EBIB, nr 24, Bibliograficzne bazy danych i ich rola w rozwoju nauki. II Konferencja Naukowa Konsorcjum BazTech, Poznań, 17-19 kwietnia 2013, http://open.ebib.pl/ojs/index.php/Mat_konf/article/ view/38/147, [dostęp: 02.02.2017].

Derfert-Wolf L., Indeksowanie czasopism naukowych $w$ krajowych bazach danych w kontekście organizacyjno-ekonomicznym, [w:] red. M. Odlanicka-Poczobutt, K. Zioło, Biblioteka akademicka. Infrastruktura, uczelnia, otoczenie, Gliwice, 24-25 października 2013 r., Gliwice 2014, s. 191-206.

Format MARC 21 rekordu bibliograficznego dla ksiażki, Warszawa 2012.

Franke J., RDA (Resource Description and Access) - geneza i koncepcja, „Przegląd Biblioteczny" 2015, R. 83, nr 1, s. 7-61.

Górny M., Standaryzacja i unifikacja - klopot czy korzyści?, [w:] Polskie biblioteki

\footnotetext{
${ }^{31}$ M. Górny, op. cit., s. 15.
} 
akademickie w Unii Europejskiej, Łódź 23-25 czerwca 2004. Materiały konferencyjne, Łódź 2004, s. 13-19.

Instrukcja obstugi programu DeskLight dla bazy BazTech, [materiały niepublikowane], oprac. 15.11.2010 z późn. zm.

Jóźwiak M., Katalog centralny NUKAT - dziesięć lat współkatalogowania, „FIDES. Biuletyn Bibliotek Kościelnych" 2014, nr 1 (38), s. 119-127.

Kasprzak Z., Polarczyk M., Nowe elementy w rozwoju bazy Agro, [w:] Materiały konferencyjne EBIB, nr 24, Bibliograficzne bazy danych i ich rola $w$ rozwoju nauki. II Konferencja Naukowa Konsorcjum BazTech, Poznań, 17-19 kwietnia 2013, http://open.ebib.pl/ojs/index.php/Mat_konf/article/view/32/144, [dostęp: 02.02.2017].

Łunarski J., Normalizacja i standaryzacja, Rzeszów 2014.

Nahotko M., Metadane, „Biuletyn EBIB” 2000, nr 6 (14), http://www.oss.wroc.pl/biu letyn/ebib14/nahotko.html, [dostęp: 02.02.2017].

Osiewalska A., BazEkon - dziedzinowy indeks cytowań z własnym programem bibliometrycznym, [w:] Materiały konferencyjne EBIB, nr 24, Bibliograficzne bazy danych $i$ ich rola $w$ rozwoju nauki. II Konferencja Naukowa Konsorcjum BazTech, Poznań, 17-19 kwietnia 2013, http://open.ebib.pl/ojs/index.php/Mat_konf/ article/view/33, [dostęp: 02.02.2017].

RDA Resource Description \& Access, Grupa Robocza ds. Standardów Bibliograficznych, http://centrum.nukat.edu.pl/rda/o-rda/, [dostęp: 02.02.2017].

Rowińska M., NUKAT. Z zasady trzymamy się zasad, „Biuletyn EBIB” 2015, nr 7 (160), http://open.ebib.pl/ojs/index.php/ebib/article/view/382, [dostęp: 02.02.2017].

Sadowska J., Polskie dziedzinowe bibliograficzne bazy danych $w$ perspektywie lokalnej i globalnej, [w:] EBIB Materiały konferencyjne, nr 19, Bibliograficzne bazy danych. Kierunki rozwoju i możliwości wspótpracy. Ogólnopolska konferencja naukowa z okazji 10-lecia bazy danych BazTech, Bydgoszcz, 27-29 maja 2009, http://www.ebib.pl/publikacje/matkonf/mat19/sadowska.php, [dostęp: 02.02.2017].

Stanula M., Polskie normy w zakresie opisu bibliograficznego dokumentów, „FIDES. Biuletyn Bibliotek Kościelnych” 1998, nr 1, s. 92-109.

Stępińska-Ustasiak L., Czasopisma humanistyczne i spoteczne otwieraja się $w$ bazie CEJSH, 2015, http://uwolnijnauke.pl/czasopisma-humanistyczne-i-spoleczne-ot wieraja-sie-w-bazie-cejsh/, [dostęp: 02.02.2017].

Strybel M., Omówienie zasad udostępiania czasopism w Bibliotece Nauki, Warszawa 2015, http://www.slideshare.net/OpenSciencePlatform/wspolpraca-z-bibliotekanauki, [dostęp: 02.02.2017].

Zamłyńska K., DML-PL Polska Matematyczna Biblioteka Cyfrowa, [w:] Materiały konferencyjne EBIB, nr 24, Bibliograficzne bazy danych i ich rola $w$ rozwoju nauki. II Konferencja Naukowa Konsorcjum BazTech, Poznań, 17-19 kwietnia 2013, http://open.ebib.pl/ojs/index.php/Mat_konf/article/view/48/148, [dostęp: 02.02.2017].

Zmiana zasad podawania autorów/twórców w hasłach głównych (pola 100/110/111) $i$ hastach dodatkowych (pola 700/710/711) oraz $w$ strefie tytutu $i$ oznaczenia odpowiedzialności, NUKAT, 2015, [dostęp: 02.02.2017], http://blog.nukat.edu.pl/ images/files/ustalenia/bibliograficzne/zasada\%20trzech_styczen_2015_tekst.pdf. 